Portland State University

PDXScholar

7-10-2013

\title{
Water track modification of soil ecosystems in the Lake Hoare basin, Taylor Valley, Antarctica
}

Joseph S. Levy

Oregon State University

Andrew G. Fountain

Portland State University, andrew@pdx.edu

Michael N. Gooseff

Pennsylvania State University - University Park

John E. Barrett

Virginia Polytechnic Institute and State University

Robert Vantreese

Montana State University - Bozeman

See next page for additional authors

Follow this and additional works at: https://pdxscholar.library.pdx.edu/geology_fac

Part of the Geochemistry Commons, Hydrology Commons, and the Soil Science Commons Let us know how access to this document benefits you.

\section{Citation Details}

Levy, J. S., Fountain, A. G., Gooseff, M. N., Barrett, J. E., Vantreese, R., Welch, K. A., ... \& Wall, D. H. Water track modification of soil ecosystems in the Lake Hoare basin, Taylor Valley, Antarctica. Antarctic Science, 1-10.

This Article is brought to you for free and open access. It has been accepted for inclusion in Geology Faculty Publications and Presentations by an authorized administrator of PDXScholar. Please contact us if we can make this document more accessible: pdxscholar@pdx.edu. 


\section{Authors}

Joseph S. Levy, Andrew G. Fountain, Michael N. Gooseff, John E. Barrett, Robert Vantreese, Kathleen A. Welch, W. Berry Lyons, Uffe N. Nielsen, and Diana H. Wall 


\title{
Water track modification of soil ecosystems in the Lake Hoare basin, Taylor Valley, Antarctica
}

\author{
JOSEPH S. LEVY ${ }^{1 *}$, ANDREW G. FOUNTAIN ${ }^{2}$, MICHAEL N. GOOSEFF ${ }^{3}$, J.E. BARRETT ${ }^{4}$, \\ ROBERT VANTREESE ${ }^{5}$, KATHY A. WELCH ${ }^{6}$, W. BERRY LYONS ${ }^{7}$, UFFE N. NIELSEN ${ }^{8,9}$ and DIANA H. WALL \\ ${ }^{1}$ College of Earth, Ocean, and Atmospheric Sciences, Oregon State University, Corvallis, OR 97331, USA \\ ${ }^{2}$ Department of Geology, Portland State University, Portland, OR 97210, USA \\ ${ }^{3}$ Department of Civil and Environmental Engineering, Pennsylvania State University, University Park, PA 16802, USA \\ ${ }^{4}$ Department of Biological Sciences, Virginia Tech, Blacksburg, VA 24061, USA \\ ${ }^{5}$ Department of Land Resources and Environmental Sciences, Montana State University, Bozeman, MT 59717, USA \\ ${ }^{6}$ Byrd Polar Research Centre and the School of Earth Sciences, Ohio State University, Columbus, OH 43210, USA \\ ${ }^{7}$ The School of Earth Sciences and Byrd Polar Research Centre, Ohio State University, Columbus, OH 43210, USA \\ ${ }^{8}$ Hawkesbury Institute for the Environment and School of Science and Health, University of Western Sydney, Penrith, \\ NSW 2751, Australia \\ ${ }^{9}$ Natural Resource Ecology Laboratory and Department of Biology, Colorado State University, Fort Collins, CO 80523, USA \\ *Current address: University of Texas Institute for Geophysics, Austin, TX 78758, USA \\ joe.levy@utexas.edu
}

\begin{abstract}
Water tracks are zones of high soil moisture that route shallow groundwater down-slope, through the active layer and above the ice table. A water track in Taylor Valley, McMurdo Dry Valleys, was analysed for surface hydrogeological, geochemical, and biological characteristics in order to test the hypothesis that water tracks provide spatial structure to Antarctic soil ecosystems by changing the physical conditions in the soil environment within the water tracks from those outside the water tracks. The presence of the water track significantly affected the distribution of biotic and abiotic ecosystem parameters: increasing soil moisture, soil salinity, and soil organic matter within the water track relative to soils outside the water track, and reducing soil phosphate, soil $\mathrm{pH}$, and the population of nematodes and other invertebrates in water track soils relative to off track soils. These results suggest that water tracks are distinct and extreme ecological zones in Taylor Valley that provide long-range (kilometre to multikilometre) structure to Antarctic hillslope ecosystems through physical control on soil moisture and solute content. Contrary to expectations, these high soil-moisture sites are not hotspots for faunal biological activity because high soil salinity makes them suitable habitats for only the most halo-tolerant organisms.
\end{abstract}

Received 1 November 2012, accepted 7 May 2013

Key words: active layer, ground water, invertebrates, McMurdo Dry Valleys, terrestrial ecosystem

\section{Introduction}

Although water is thought to be the primary limiting factor determining the distribution and abundance of life in Antarctic soils (Kennedy 1993), the diversity and abundance of nematodes and other invertebrates at the highest trophic level in the McMurdo Dry Valleys (MDV) terrestrial ecosystem (Virginia \& Wall 1999) have been found to depend on a range of soil physical and chemical factors. The spatial distribution of soil moisture, soil salinity, and nutrient availability have all been shown to provide spatial structure to Antarctic soil ecosystems (Freckman \& Virginia 1997, Virginia \& Wall 1999, Poage et al. 2008). The spatial distribution of the physical parameters that influence biological processes has been found to vary in Antarctic soils as a function of elevation, landform/landscape position, and sampling scale (Powers et al. 1998, Lyons et al. 2000, Barrett et al. 2004, Barrett et al. 2009). Soil ecosystem characteristics in Taylor Valley
(Fig. 1) depend strongly on proximity to perennial moisture sources, including the shores of perennially ice-covered valley-bottom lakes, ephemeral stream channels, water tracks from snow packs and permafrost/ground ice (Barrett et al. 2004, Barrett et al. 2009, Nielsen et al. 2012, Smith et al. 2012).

Water tracks are topographically-controlled permafrost groundwater conduits that route water derived from snowmelt, ground ice melt, and brine migration downslope, above the ice table, in polar environments (Hastings et al. 1989, McNamara et al. 1999, Levy et al. 2011) (Fig. 2). Water tracks route much of the water and solute flux on Arctic hill slopes (Hastings et al. 1989, McNamara et al. 1999). Shallow groundwater flow through water tracks provides hydraulic connectivity within the active layer (Stieglitz et al. 2003), making water track spatial distribution and hydraulic discharge a primary determinant of sediment and nutrient fluxes from Arctic hill slopes (Bowden et al. 2008). Enhanced availability of liquid 


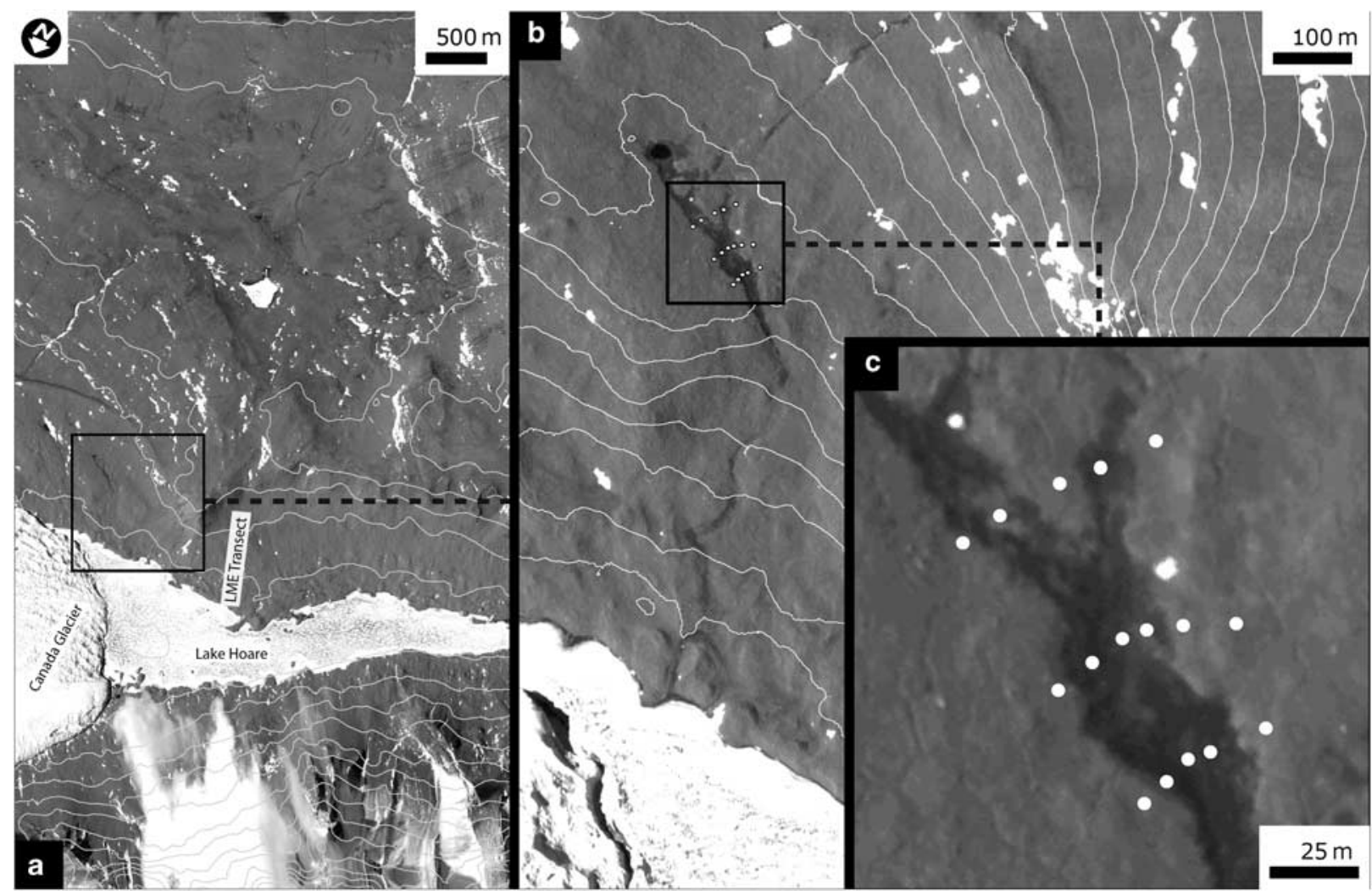

Fig. 1. A water track in the Lake Hoare basin, Taylor Valley, Antarctica. a. Context view of the Lake Hoare basin in Taylor Valley, McMurdo Dry Valleys. Contours are $100 \mathrm{~m}$ apart. 'LME Transect' indicates the location of the Long-term Manipulation Experiment (LME) transect described by Virginia \& Wall (1999) and Powers et al. (1998). Box shows image area in part b. b. Landscape scale view of WT1, the water track studied in this project. The water track is visible as dark, damp soil moving down-slope from image top to bottom. White circles indicate soil sampling sites. Contours are $10 \mathrm{~m}$. c. Zoomed in view of sampling transect used in this study. Base map is Ikonos satellite image orthoqb02_10jan142105572-p1bs-101001000af0d300_u08ns4326. Image has been stretched to enhance contrast.

water in water track soils makes them biological hotspots with dramatically increased carbon concentrations, driving carbon cycling on Arctic permafrost hill slopes (McNamara et al. 2008).

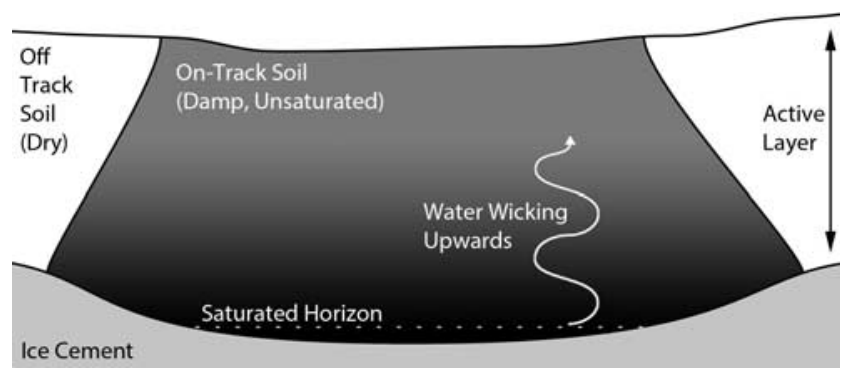

Fig. 2. Schematic illustration of a cross-section of a water track. The cross-section is oriented orthogonal to the flow direction. Meltwater flows along the ice cement (the base of the thawed active layer), and wicks upwards from a saturated portion of the water track to unsaturated sediments at the surface. Typical water tracks are several metres wide and up to $60 \mathrm{~cm}$ deep. This schematic illustration is not to scale.
Water tracks have been recently identified in Taylor Valley, Antarctica $\left(77.63^{\circ} \mathrm{S}, 162.91^{\circ} \mathrm{E}\right)$, where they have been shown to provide hydrological connectivity from upland terrains to valley bottoms (Levy et al. 2011). Water tracks move snowmelt and ground ice melt through the active layer during summer months, routing moisture, salts, and rock weathering products down-slope over distances of hundreds of metres to kilometres (Levy et al. 2011). Water tracks are easily identified in the MDV, appearing as linear to sub-linear patches of soil that are darker and wetter than adjacent dry, light-coloured soils (Levy et al. 2011). Water tracks occasionally discharge at the ground surface, producing saline ponds and seeps (Lyons et al. 2005, Harris et al. 2007, Levy et al. 2011, Nielsen et al. 2012). Water tracks also discharge into valley-bottom lakes.

In this manuscript, we test the hypothesis that water tracks provide spatial structure to soil ecosystems at the metre to tens of metres length scale by changing soil moisture, salinity, and nutrient flux states for soils inside the water track versus soils outside the water track. This hypothesis is important for understanding Antarctic 
terrestrial ecosystem processes because water tracks operate at kilometre length scales across the landscape, tend to re-occur each melt season in the same locations, and may be a hydrological feature that provides hill slope scale connectivity within Antarctic ecosystems.

\section{Research site}

The McMurdo Dry Valleys span an ice sheet-free region between the Transantarctic Mountains of southern Victoria Land and the Ross Sea. Taylor Valley, one of the McMurdo Dry Valleys, is a c. $50 \mathrm{~km}$ long valley centred on $77.7^{\circ} \mathrm{S}, 162.6^{\circ} \mathrm{E}$, and has been the focus of the McMurdo Dry Valleys Long-term Ecological Research project (MCM-LTER) since 1993.

The portions of the surface of Taylor Valley that are not characterized by lakes, streams, glaciers, or bedrock are covered by a poorly weathered soil composed of glacial drift, valley-wall colluvium, marine sediments, and palaeolake beds (Bockheim et al. 2008). With a mean annual temperature of $c .-18^{\circ} \mathrm{C}$ (Doran et al. 2002), Taylor Valley soils are perennially frozen, forming continuous permafrost to a depth of c. 200-600 m (McGinnis \& Jensen 1971, Decker \& Bucher 1980). Much of this permafrost is icecemented, however, the low atmospheric water vapour pressure in Taylor Valley (Clow et al. 1988) results in the removal of shallow ground ice by vapour diffusion (Hagedorn et al. 2007). Accordingly, based on observations of the upper $c .1 \mathrm{~m}$ of Taylor Valley soils, approximately half have been mapped as dry frozen (ice-free to $c .1 \mathrm{~m}$ depth), while half are shallowly ice-cemented (Bockheim et al. 2007). Summer warming of the soil surface results in thawing of the upper $c .10-60 \mathrm{~cm}$ of the permafrost, resulting in the formation of an active layer (Bockheim et al. 2007). In some locations the active layer is nearly dry, while in other locations it is meltwater-saturated (Campbell et al. 1997, Marchant \& Head 2007), potentially leading to water track formation.

Water track formation is controlled not just by temperature, but also by topography, insolation, precipitation, melting, and the overall energy balance of the ground system (soil, ground ice, snow etc.) (Levy et al. 2011, Levy et al. 2012a). Therefore, here we provide background into the surface energy balance forcing at work in water tracks in the Lake
Hoare basin of Taylor Valley. Data from the MCM-LTER indicates that soil temperature at the ground surface averages $-18.4^{\circ} \mathrm{C}$, and spans a seasonal range from $c .-48^{\circ} \mathrm{C}$ to $+23^{\circ} \mathrm{C}$ (data from www.mcmlter.org, accessed October 2012). In this manuscript, we consider "on track" samples collected from within the darkened portion of the water track and "off track" samples collected from the dry, light-toned sediments, located at least $5 \mathrm{~m}$ from the current edge of the water track (defined by the spatial extent of surface darkening associated with water track moisture). Wet (on track) soils are typically warmer than dry (off track) soils in the summer by $c .2-4^{\circ} \mathrm{C}$ and are typically colder in the winter by $c$. $2-4^{\circ} \mathrm{C}$, owing to reduced albedo during the summer driving increased shortwave absorption into water tracks, and due to increased thermal diffusivity of ice-cemented water track soils causing rapid heat loss in the winter (Levy et al. 2012a). The albedo of wet, on track soils is typically c. 0.15 , while the albedo of dry, off track soils is typically c. 0.22 , based on hemispheric shortwave radiometer measurements of water track 1 (WT1) (the water track described below).

The water track analysed in this study, WT1 (Levy et al. $2011)$, is located in the Lake Hoare basin $\left(77.63^{\circ} \mathrm{S}\right.$, $\left.162.92^{\circ} \mathrm{E}\right)$ on a north-facing slope on the south side of the ice-covered lake (Fig. 1). The north side of the Lake Hoare basin is characterized by steep slopes $\left(20-25^{\circ}\right)$ and exposed bedrock, with thin, colluvial soil cover resulting from debris-flows and debris avalanches. The south side of the basin has a more gentle slope $\left(5-10^{\circ}\right)$ with thicker soils that do not show evidence of energetic mass wasting. This orientation-dependent slope asymmetry is typically attributed to enhanced soil creep via freeze-thaw processing, which occurs preferentially on warm, equatorfacing slopes (the south wall of Taylor Valley faces north) (Marchant \& Head 2007). In contrast, on colder, polefacing slopes, sediment transport occurs primarily via debris avalanches and sporadic debris flows. Soil creep produces gentler slopes on warm valley walls, while steep, bedrock dominated slopes are preserved on cold, pole-facing walls.

Water track 1 drains the western Kukri Hills, and flows for $c .2 \mathrm{~km}$ down-slope from the Nussbaum Riegel to the shore of Lake Hoare. The water track width ranges from c. $1-25 \mathrm{~m}$, and is narrowest along steep slopes (up to $10^{\circ}$ )

Table I. Summary of grain size distributions for six soil samples collected by this project.

\begin{tabular}{lccccccc}
\hline Sample & On/off track & Total wt $(\mathrm{g})$ & $\%>2 \mathrm{~mm}^{5}$ & $\% 2-0.063 \mathrm{~mm}^{4}$ & $\% 63-15 \mu \mathrm{m}^{3}$ & $\% 15-2 \mu \mathrm{m}^{2}$ & $\%<2 \mu \mathrm{m}^{1}$ \\
\hline BIO13G & On & 35.94 & 30.5 & 58.0 & 5.5 & 3.8 & 2.9 \\
BIO16G & On & 53.49 & 18.8 & 72.6 & 52.4 & 2.1 & 2.6 \\
BIO18G & On & 41.91 & 43.4 & 62.2 & 1.7 & 0.8 \\
BIO15G & Off & 122.43 & 35.0 & 49.3 & 0.7 & 0.4 \\
BIO25G & Off & 142.56 & 49.0 & 83.7 & 0.3 & 0.4 \\
BIO30G & Off & 55.11 & 14.7 & & 0.3 \\
\hline
\end{tabular}

On $v s$ off track ANOVA values: ${ }^{1} P=0.04,{ }^{2} P=0.07,{ }^{3} P=0.06,{ }^{4} P=0.76,{ }^{5} P=0.88$. 
and widest where the water track is deflected around an ice-cored moraine, producing surface ponding. Typically, the water track is c. $3 \mathrm{~m}$ wide. Groundwater flow velocity for WT1 is typically c. $1.8 \times 10^{-3} \mathrm{~cm} \mathrm{~s}^{-1}$ during peak summer flow (Levy et al. 2011), which is typical of groundwater velocities on low Taylor Valley slopes. Water track flow rates on steep walled portions of the valley can reach up to $7.9 \times 10^{-2} \mathrm{~cm} \mathrm{~s}^{-1}$ (Levy 2012). During low flow periods, water track groundwater has been observed to pond in depressions of the ice table, during which time flow velocities drop to zero.

Here we describe the soil environment in which WT1 is found. Water track 1 flows through a sandy, skeletal calcic haplorthel soil (Campbell 2003) comprised overwhelmingly of a homogenous mixture of coarse quartzofeldspathic sand and pebbles and capped by a pebble/cobble desert pavement - similar to most Lake Hoare basin soils, which contain $>80 \%$ sand in the upper $40 \mathrm{~cm}$ of the soil column, with pebbles dominating the remainder of the sediment (Campbell 2003). On and off track soils are indistinguishable in their coarse fraction (pebbles and granules $>2 \mathrm{~mm}$ ) and in their sand fraction (Table I). Notably, however, on track soils have a greater abundance of silt- and clay-sized particles than off track soils (Table I). A comparable assemblage of clays, salts, and other weathering products are found in both on and off track soils, as determined by x-ray diffraction (XRD) analysis of
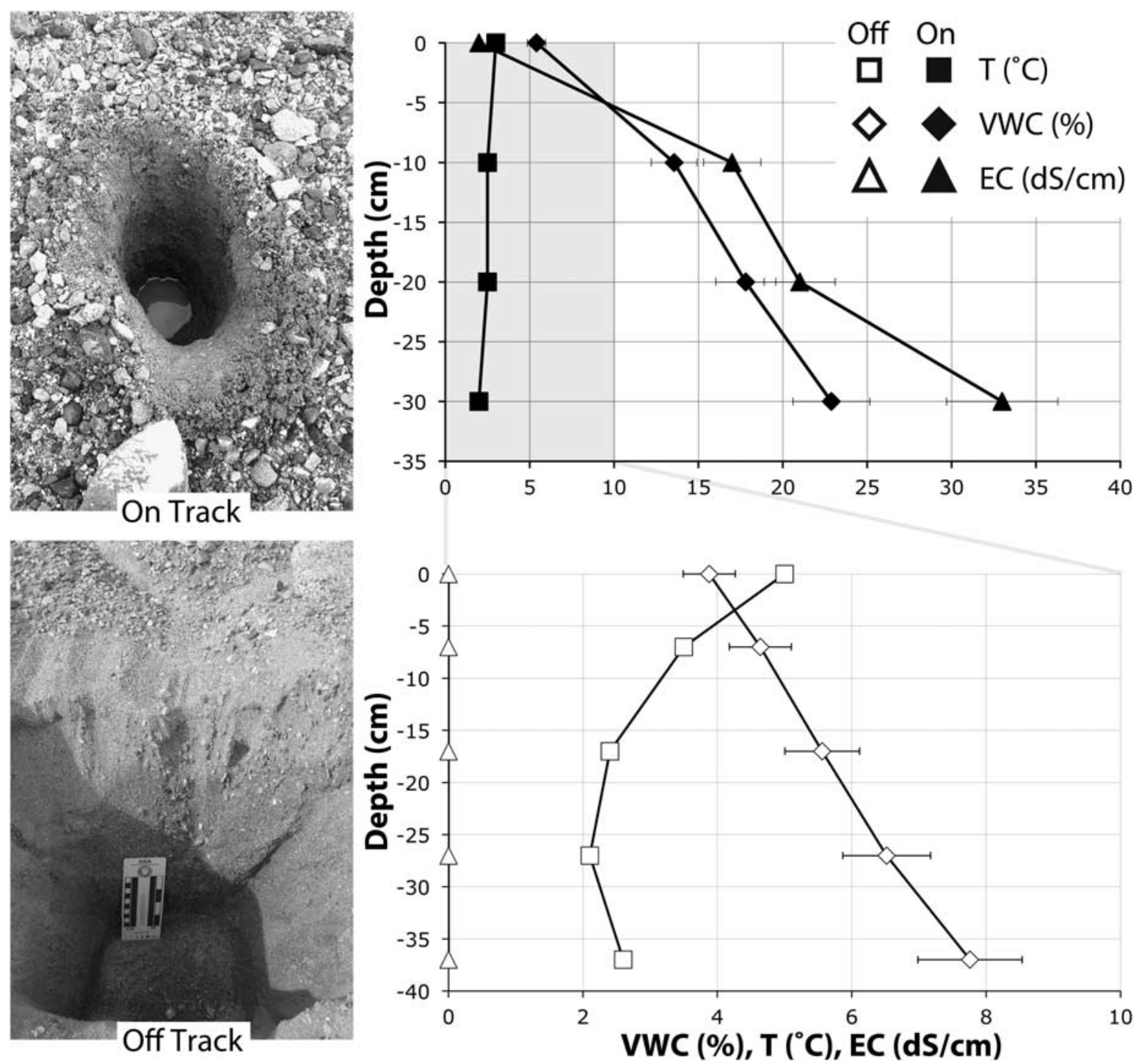

Fig. 3. Soil profiles and physical properties of typical on track (above) and off track (below) sample sites. Water track soils are wetter, more saline, and more isothermal than off track soils. Note that the range of parameters in the off track plot fits in the grey area of the on track plot. On track measurement was made on 23 December 2009 at $-77.63250^{\circ} \mathrm{N}, 162.93335^{\circ} \mathrm{E}$. Off track measurement was made on 5 January 2010 at $-77.64231^{\circ} \mathrm{N}, 162.80145^{\circ} \mathrm{E}$. Error bars represent instrument uncertainty, and are smaller than the symbols for temperature. 
Table II. Summary of biogeochemical data for water track sample sites.

\begin{tabular}{|c|c|c|c|c|c|c|c|c|c|c|c|c|c|c|}
\hline & $\begin{array}{l}\text { Nematod } \\
\text { Live }\end{array}$ & $\begin{array}{c}\text { umber } 1 \\
\text { Dead }\end{array}$ & $\begin{array}{c}\text { dry soil) } \\
\text { Total }\end{array}$ & $\begin{array}{l}\text { VWC } \\
(\%)\end{array}$ & $\begin{array}{c}\text { EC } \\
\left(\mathrm{dS}^{-1}\right)\end{array}$ & $\begin{array}{l}\text { AFDM } \\
\text { (wt \%) }\end{array}$ & $\begin{array}{c}\mathrm{NH}_{4} \\
\left(\mu \mathrm{g}^{-1}\right)\end{array}$ & $\begin{array}{c}\mathrm{PO}_{4} \\
\left(\mu \mathrm{g} \mathrm{l}^{-1}\right)\end{array}$ & $\begin{array}{c}\mathrm{NO}_{3} \\
\left(\mu \mathrm{g} \mathrm{l}^{-1}\right)\end{array}$ & $\begin{array}{c}\mathrm{NO}_{2} \\
\left(\mu \mathrm{g} \mathrm{l}^{-1}\right)\end{array}$ & $\begin{array}{c}\mathrm{Cl} \\
(\mathrm{mM})\end{array}$ & $\begin{array}{c}\text { TDS } \\
\left(\mathrm{mg} \mathrm{l}^{-1}\right)\end{array}$ & $\mathrm{pH}$ & $\begin{array}{c}\text { MB } \\
(\mu \mathrm{g} \mathrm{C} / \mathrm{g} \text { soil })\end{array}$ \\
\hline Mean on track & 17.8 & 9.3 & 27.1 & 10.9 & 2.7 & 1.2 & 27.8 & 55.5 & 6718.8 & 6.3 & 29.5 & 1836.1 & 8.6 & 7.9 \\
\hline Mean off track & 83.8 & 19.4 & 103.3 & 1.4 & 0.4 & 0.4 & 38.2 & 164.4 & 860.4 & 4.8 & 2.5 & 294.5 & 9.6 & 14.6 \\
\hline $\mathrm{SD}$ on track & 37.5 & 26.6 & 61.7 & 9.2 & 3.0 & 1.0 & 35.9 & 49.6 & 13336.4 & 7.5 & 35.7 & 2161.3 & 0.6 & 15.0 \\
\hline SD off track & 134.1 & 23.3 & 151.1 & 3.0 & 0.5 & 0.1 & 64.4 & 295.0 & 1942.4 & 2.2 & 3.3 & 397.5 & 0.6 & 12.9 \\
\hline
\end{tabular}

$\mathrm{VWC}=$ volumetric water content, $\mathrm{EC}=$ electrical conductivity, $\mathrm{AFDM}=$ ash-free dry mass, $\mathrm{TDS}=$ total dissolved solids, $\mathrm{MB}=$ microbial biomass, $\mathrm{SD}=$ standard deviation

the sieved and expanded (K-saturation and Mg-saturation) clay fraction. Clay particles present are composed of illite, smectite, chlorite, aragonite, calcite, sepiolite, talc, and vermiculite. The main difference between on and off track soils being the abundance of these clay/silt phases, rather than the composition. No weathering horizons are present in the water track soils - either on or off the track.

On and off track soils are most clearly distinguished by their soil moisture, salinity, and temperature profile. Water track soils are wetter, more saline, and more isothermally warm (during summer) than adjacent off track soils (Fig. 3). Generally, soil moisture and electrical conductivity (EC) (salinity) increase with depth in water track soils (Fig. 3), while off track soils have relatively homogenous salinity profiles with depth (although soil moisture typically increases with depth in the active layer as a consequence of diffusion of water vapour from the base of the ice table (Hagedorn et al. 2007).

\section{Sample collection and processing}

Soil samples were collected from the upper $10 \mathrm{~cm}$ of the soil column during a two-week period in November and December of 2010 in a series of transects orthogonal to the flow path of WT1. Transects were spaced c. $50 \mathrm{~m}$ apart, with $5-10 \mathrm{~m}$ between sample points. At each sampling point, c. $500 \mathrm{~g}$ of soil was collected with a clean polyethylene scoop that had been rinsed with deionized (DI) water prior to sampling, and placed into clean Whirl-Pak bags. Samples were transported to McMurdo Station and were stored at $-20^{\circ} \mathrm{C}$ for approximately one week. Samples were homogenized and then split for physical, chemical, and biological analyses. Splits for nematode counts were kept at $+4^{\circ} \mathrm{C}$ during processing. Splits for physical/chemical analyses were thawed at ambient temperatures in the A.P. Crary Science and Engineering Center and were processed immediately after thawing.

Samples were analysed for invertebrate abundance, ash-free dry mass (AFDM), microbial biomass, soil $\mathrm{pH}$, soil EC, soil major ions $\left(\mathrm{Ca}^{2+}, \mathrm{Mg}^{2+}, \mathrm{K}^{+}, \mathrm{Na}^{+}, \mathrm{Cl}^{-}, \mathrm{SO}_{4}{ }^{2-}\right.$, $\mathrm{NO}_{3}{ }^{-}$, and $\left.\mathrm{F}^{-}\right)$, water-soluble nutrient concentration $\left(\mathrm{NO}_{2}\right.$, $\mathrm{NO}_{3}, \mathrm{NH}_{3}$, and $\mathrm{PO}_{4}$ ), and gravimetric water content.

For soil pH, EC, major ion analysis, and nutrients analysis, c. $100 \mathrm{~g}$ sample splits were mixed with DI water in a 1:3 ratio of soil to water by mass and agitated for approximately one minute. These soluble phase extracts were then filtered using $0.45 \mu \mathrm{m}$ HT Tuffryn membrane filters into pre-cleaned polyethylene bottles. Major ion concentrations were determined by ion chromatography as described in Welch et al. (2010) resulting in a total analytical error of $<4 \%$. Soluble phase extract $\mathrm{pH}$ was measured using a calibrated IQ Scientific pH meter, and extract EC was measured using a Decagon Devices 5TE electrical conductivity probe connected to a Decagon Devices ProCheck reader, resulting in measurement uncertainties of \pm 0.1 and $10 \%$, respectively.

Table III. Pearson correlation matrix of water track ecosystem properties $(n=27)$.

\begin{tabular}{|c|c|c|c|c|c|c|c|c|c|c|c|}
\hline & live + dead & $\begin{array}{c}\text { VWC } \\
\%\end{array}$ & $\begin{array}{c}\text { EC } 1: 3 \\
\left(\mathrm{dS} \mathrm{m}^{-1}\right)\end{array}$ & $\begin{array}{l}\text { AFDM } \\
\text { wt } \%\end{array}$ & $\begin{array}{l}\mathrm{NH}_{4}-\mathrm{N} \\
\left(\operatorname{ug~l}^{-1}\right)\end{array}$ & $\begin{array}{l}\mathrm{PO}_{4}-\mathrm{P} \\
\left(\mathrm{ug}^{-1}\right)\end{array}$ & $\begin{array}{c}\mathrm{NO}_{3} \\
\left(\mathrm{ug} \mathrm{l}^{-1}\right)\end{array}$ & $\begin{array}{c}\mathrm{NO}_{2} \\
\left(\mathrm{ug} \mathrm{l}^{-1}\right)\end{array}$ & $\begin{array}{l}\text { Cl 1:3 } \\
(\mathrm{mM})\end{array}$ & $\begin{array}{l}\text { TDS 1:3 } \\
\left(\mathrm{mg} \mathrm{l}^{-1}\right)\end{array}$ & $\begin{array}{c}\mathrm{MB} \\
\left(\operatorname{ug~g}^{-1}\right)\end{array}$ \\
\hline live + dead & 1 & & & & & & & & & & \\
\hline EC $1: 3\left(\mathrm{dS} \mathrm{m}^{-1}\right)$ & -0.58 & 0.36 & 1 & & & & & & & & \\
\hline AFDM wt \% & -0.3 & 0.56 & 0.61 & 1 & & & & & & & \\
\hline $\mathrm{NH}_{4}-\mathrm{N}\left(\right.$ ug l $\left.^{-1}\right)$ & 0.04 & -0.1 & 0.11 & 0.01 & 1 & & & & & & \\
\hline $\mathrm{PO}_{4}-\mathrm{P}\left(\mathrm{ug} \mathrm{l}^{-1}\right)$ & 0.21 & -0.04 & -0.34 & 0.03 & 0.1 & 1 & & & & & \\
\hline $\mathrm{NO}_{2}\left(\mathrm{ug} \mathrm{l}^{-1}\right)$ & -0.09 & 0.13 & 0.14 & 0.16 & 0.28 & -0.1 & 0.15 & 1 & & & \\
\hline $\mathrm{Cl}(\mathrm{mM}) 1: 3$ & -0.57 & 0.33 & 0.95 & 0.55 & 0.14 & -0.33 & 0.76 & 0.05 & 1 & & \\
\hline $\operatorname{TDS} 1: 3\left(\mathrm{mg} \mathrm{l}^{-1}\right)$ & -0.56 & 0.25 & 0.92 & 0.53 & 0.18 & -0.26 & 0.78 & 0.03 & 0.94 & 1 & \\
\hline MB (ug g $\left.{ }^{-1}\right)$ & 0.36 & -0.09 & -0.31 & -0.23 & 0.34 & 0.19 & -0.13 & -0.01 & -0.25 & -0.22 & 1 \\
\hline
\end{tabular}

$\mathrm{VWC}=$ volumetric water content, $\mathrm{EC}=$ electrical conductivity, $\mathrm{AFDM}=$ ash-free dry mass, TDS $=$ total dissolved solids, and MB $=$ microbial biomass. 

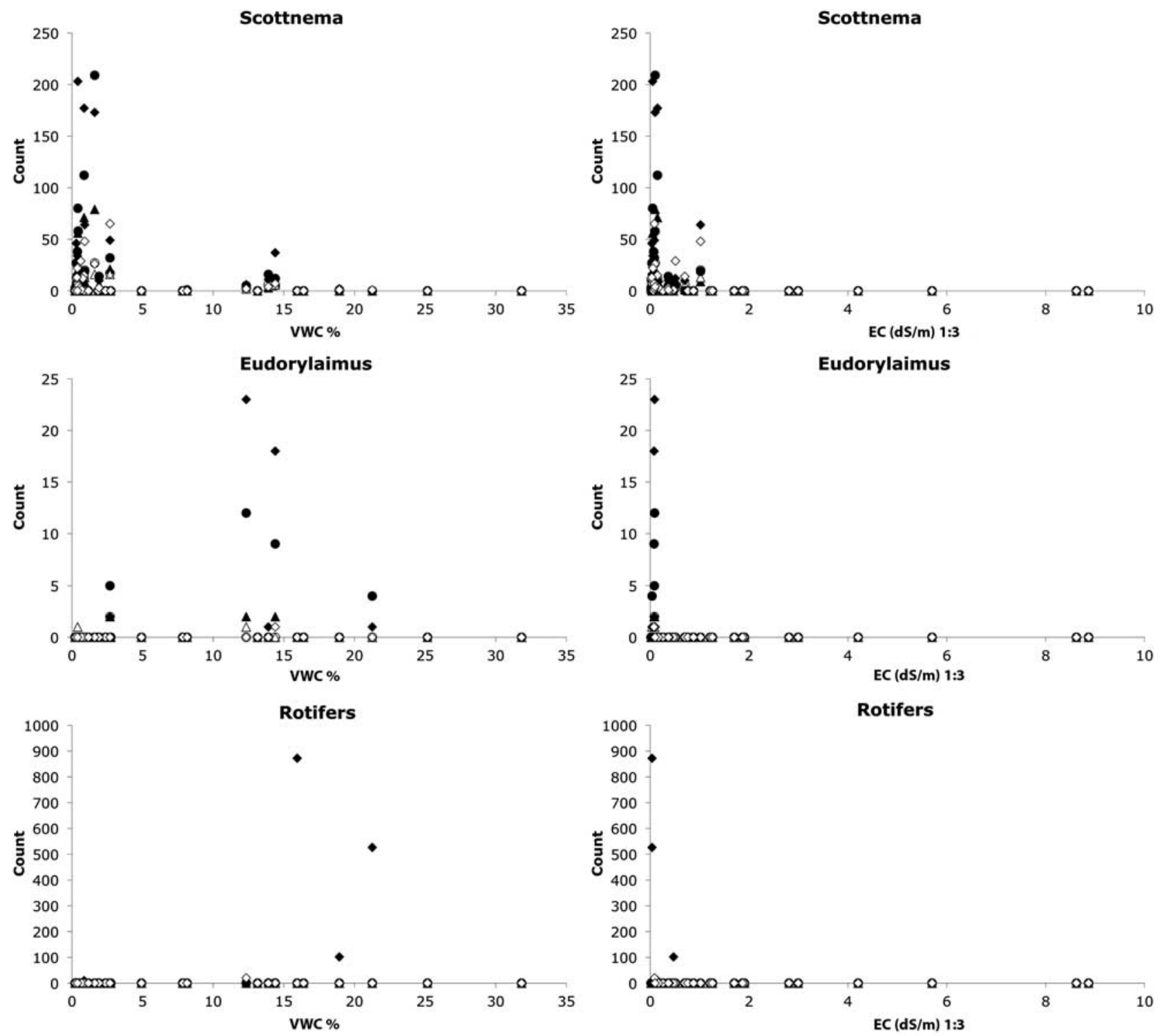

\section{$\Delta \Delta$ Males (Live/Dead) \\ - $\bigcirc$ Females (Live/Dead) \\ $\diamond \diamond$ Juvenilles (Live/Dead)}

Fig. 4. Plots of invertebrate abundance in water track (on and off track) samples versus volumetric water content (VWC\%) and electrical conductivity (EC) measured in 1:3 rock/water dilutions.

Washed and filtered soluble phase extracts were analysed for nutrient content using a Lachat Flow Injection Analyser (QuickChem Model 8000; Hach Instruments, Loveland, CO, USA). Hach methods were optimized for low level detection, and based on 10-107-06-1 (alkaline phenolate), 10-107-04-1 (Cd reduction/sulfanilamide), and 10-115-01-1 (ascorbate/molybdate), for $\mathrm{NH}_{4}, \mathrm{NO}_{x}$, and $\mathrm{PO}_{4}$, respectively. Standard detection levels are c. 2 ppb for $\mathrm{NO}_{\mathrm{x}}, c .2 \mathrm{ppb}$ for $\mathrm{PO}_{4}$, and c. 2 ppb for $\mathrm{NH}_{4}$.

Microbial biomass of sediments was measured as chloroform labile $\mathrm{C}$ using the chloroform fumigation incubation method modified for low biomass samples
(Cheng \& Virginia 1993). Approximately $20 \mathrm{~g}$ of soil (dry weight equivalent) was incubated in a vacuum desiccator under a chloroform atmosphere for five days. Fumigated and paired non-fumigated samples were then extracted with $50 \mathrm{ml} 0.5 \mathrm{M} \mathrm{K}_{2} \mathrm{SO}_{4}$ and final extracts analysed for total organic carbon using a OI Model 1010 Total Organic Carbon Analyser (OI Analytical, College Station, TX, USA), where final chloroform-labile carbon was calculated as the difference between fumigated and non-fumigated soil total organic matter.

Volumetric water content was measured by weighing a c. $100 \mathrm{~g}$ split of each sample and drying the sample at 
$105^{\circ} \mathrm{C}$ for 24 hours. Dried samples were reweighed to determine the gravimetric water content (GWC, in $\left.\mathrm{g}_{\text {water }} / \mathrm{g}_{\text {sample }}\right)$. Gravimetric water content values were converted to volumetric water content (VWC) values by multiplying the GWC by $1.8 \mathrm{~g} \mathrm{~cm}^{-3}$, the mean bulk density of water track soils (Levy et al. 2011). Dried samples were measured for AFDM (total organic matter) by pyrolysis. Approximately $10 \mathrm{~g}$ splits of the dried samples were weighed on a Mettler analytical balance $(0.1 \mathrm{mg}$ precision), and were baked in aluminum foil packets in a muffle furnace at $500^{\circ} \mathrm{C}$ for one hour. Baked samples were reweighed to determine mass loss, which is inferred to indicate pyrolysis of organic matter.

Nematode, rotifer, and tardigrade counts were conducted on sample splits that had been brought from $-20^{\circ} \mathrm{C}$ to $-4^{\circ} \mathrm{C}$ and stored for approximately two weeks in an environmental room, McMurdo Station, until processed. The samples were then stepped to $+4^{\circ} \mathrm{C}$, homogenized gently, and soil invertebrates were extracted from approximately $100 \mathrm{~g}$ wet soil using a standard sugar centrifugation method (Freckman et al. 1977, Nielsen et al. 2012). All nematodes were identified to species level, and live rotifers and tardigrades were counted. Counts were transformed to individuals per $\mathrm{kg}$ dry soil.

Raw data were transformed to $\ln (n+1)$, where $n$ is the raw data value, to satisfy the assumption of normal data distribution, and were analysed by single factor ANOVA to test for statistically significant differences between soil ecosystem parameters within WT1 ("on track") and outside of WT1 ("off track"). A total of 27 samples were analysed, 13 on track and 14 off track. Water track soil ecosystem analyses are summarized in Table I.

\section{Results}

The principal ecosystem factors that define differences between WT1 and off track soils are VWC, EC, $\mathrm{PO}_{4}{ }^{3-}$ content, $\mathrm{Cl}^{-}$concentration, total dissolved solids (TDS), $\mathrm{pH}$, and soil AFDM (Table II). Water track 1 soils have significantly higher VWC than off track soils, higher EC than off track soils, lower $\mathrm{PO}_{4}{ }^{3-}$ content than off track soils, higher $\mathrm{Cl}^{-}$and TDS than off track soils, lower $\mathrm{pH}$ than off track soils, and higher AFDM than off track soils. Because $\mathrm{Cl}^{-}$is a dominant dissolved salt in WT1, and is also an electrolyte, it is not surprising that EC, TDS, and $\mathrm{Cl}^{-}$ content are all strongly correlated (Table III). Nutrient concentrations show variable behaviour on and off WT1. $\mathrm{NO}_{3}$ is one (and in places, two) orders of magnitude more concentrated in WT1 soils than in adjacent, off track soils. Both $\mathrm{NH}_{4}$ and $\mathrm{NO}_{2}$ concentrations are similar in on and off track soils.

These differences in ecosystem parameters correlate with differences in invertebrate abundances in soils on and off WT1 (Table III). Nematodes are two to four times more common in off track soils than in on track soils, for live, dead, and total nematode counts (however, $P$ values for these populations are only 0.07, 0.13, and 0.08 respectively). Nematodes are exceptionally uncommon in WT1 soils (mean 27.1 total nematodes per kg dry soil), and were also uncommon in nearby off track soils (mean 103.3 total nematodes per $\mathrm{kg}$ dry soil). Of the nematodes, Scottnema lindsayae Timm (a microbial feeder) is the most common (Fig. 4), followed by Eudorylaimus antarcticus (Steiner) Yeates (an algal feeder). Individual Plectus antarcticus de Man (also a microbial feeder) were found in some samples, but they are largely absent from WT1 samples. Small numbers of rotifers are the only other invertebrate found in the water track samples.

Measurements of soil microbial biomass yielded complex results. Microbial biomass averaged $7.9 \mu \mathrm{g} \mathrm{C}$ per $\mathrm{g}_{\text {dry-soil }}$ $(\sigma=15.0)$ for on track samples and $14.6 \mu \mathrm{g} \mathrm{C}$ per $\mathrm{g}_{\text {dry-soil }}$ $(\sigma=12.9)$ for off track samples. When these data are $\log$ and constant transformed $(\ln \mathrm{X}+\mathrm{n})$, no significant difference emerges for soil microbial biomass for WT1 on and off track samples due to high variance in on track values (up to $54.4 \mu \mathrm{g} \mathrm{C}$ per $\mathrm{g}_{\text {dry-soil }}$ ). Microbial biomass is not strongly correlated with any biotic or abiotic factor, but may be influenced in part by nematode abundance (predation) and soil $\mathrm{NH}_{4}$ content (Table II). Interestingly, the high microbial biomass samples are associated with samples collected from sites containing surficial algal mats. When algal mat sites are excluded from the analysis, on track sediments are found to average $6.1 \mu \mathrm{g} \mathrm{C}$ per $\mathrm{g}_{\text {dry-soil, }}$, while off track sediments average $19.4 \mu \mathrm{g} \mathrm{C}$ per $\mathrm{g}_{\text {dry-soil }}$, with $P<0.01$.

\section{Discussion}

The water track we studied in the Lake Hoare basin of Taylor Valley appears to influence the physical and chemical environment of these soil ecosystems. Nematodes were the dominant invertebrate in both on and off track soils and the paucity of nematodes within the water track is consistent with field and laboratory measurements of nematode habitat suitability (Nkem et al. 2006). Nematode populations reported here are significantly lower than the total nematode abundances reported for Lake Hoare basin soils located at a Long-Term Manipulation Experiment site located $1.25 \mathrm{~km}$ from the water track (Freckman \& Virginia 1997, Virginia \& Wall 1999), in an altitude transect that spans comparable elevation ranges to WT1. Along this transect, Powers et al. (1998) found an average of 958 total nematodes per $\mathrm{kg}$ dry soil. For comparison, $P$ values between the Powers et al. (1998) populations and populations on and off water tracks are 0.001 and $<0.001$, respectively, indicating that water track and circum-water track nematode populations are significantly smaller than nematode populations at the Long-Term Manipulation Experiment site. Although water track environments span the range of soil water contents suitable for Scottnema (c. $<10 \%$ VWC) and Eudorylaimus (c. $>15 \%$ VWC) 
(Virginia \& Wall 1999), the salinities of WT1 and near-water-track soils greatly exceed the limits for nematode suitability observed in the field $\left(c .2 \mathrm{dS} \mathrm{m}^{-1}\right.$ for $S$. lindsayae and $c .1 \mathrm{dS} \mathrm{m}^{-1}$ for E. antarcticus) (Courtright et al. 2001, Poage et al. 2008). Generally, where present, the nematodes fall well within their most suitable habitats, with Scottnema being abundant in drier and saltier soils, and Plectus being present in wetter, low-salinity soils (Fig. 4) (Virginia \& Wall 1999).

Curiously, while nematodes are uncommon in WT1 soils, total soil organic matter is three times greater within WT1 than in adjacent off track soils (means: $1.2 \mathrm{wt} \%$ and $0.4 \mathrm{wt} \%$, respectively, although in places, on track soils contain an order of magnitude more organic matter than adjacent off track soils). The low number of nematodes in WT1 soils is consistent with the Barrett et al. (2007) observation that invertebrates are uncommon in highnitrate MDV soils. However, WT1 soils are also strongly depleted in phosphorus as compared to off track soils, having average N:P molar ratios of 269:1 and 12:1, respectively, as compared to 1:1 for typical MDV soils (Barrett et al. 2007). These data suggest that, hydrological processes (e.g. shallow groundwater flow) may be concentrating nitrite derived from atmospheric deposition (Michalski et al. 2005) in WT1 when snow melts and flows into the water tracks, increasing nitrate concentrations in water track soils relative to phosphorous concentrations (Bate et al. 2008). Emplacement of nitrate salts along water track edges during periods of intense flow and broad surface wetting may account for the relative increase in $\mathrm{N}$ concentrations in nearby off track soils above typical MDV background values. The depletion of phosphate in WT1 soils relative to off track soils may result from mobilization of phosphate down-slope. The non-biological stoichiometry of $\mathrm{N}$ and $\mathrm{P}$ in this water track suggest that these element cycles are dominated by abiotic drivers. Alternatively, the low phosphate contents may reflect early season sampling conditions, when biomass, and accordingly, biotic P, would be expected to be lower than peak summer values (e.g. Barrett et al. 2007).

Could the presence of microbial communities in WT1 account for the high organic matter content of on track soils determined by loss on ignition? These microorganisms would be expected to be abundant in the presence of abundant water, soluble nutrients, and in the absence of predation by microbivore nematodes that are excluded by high salt concentrations in the water tracks. Microbial biomass measurements made on WT1 soils indicate that on track soils are, on average, less enriched in microbial carbon than off track soils, except where algal mats exist within the water track. We speculate that the apparent contradiction between the AFDM results and the microbial biomass results may indicate that water tracks act as an interface between two different carbon pools in the MDV. High total organic matter contents in WT1 may indicate enrichment in allochthonous carbon - organic material preserved in the water track due to high salt contents in water track fluids. Water track algal mats may be sites where labile carbon is generated in abundance, which is then exported deeper into the soil column or downstream and mineralized into passive carbon. Alternatively, because these samples were collected in the early summer (26 November 2010), it is possible that peak summer productivity and labile carbon consumption are not reflected in water track and off track samples. In such a case, these preliminary results indicate disequilibrium mid-season conditions, and are not representative of long-term biological processes in WT1. Enhanced water track sediment sampling in 2013-14 will help address these outstanding issues on carbon-cycling in water tracks.

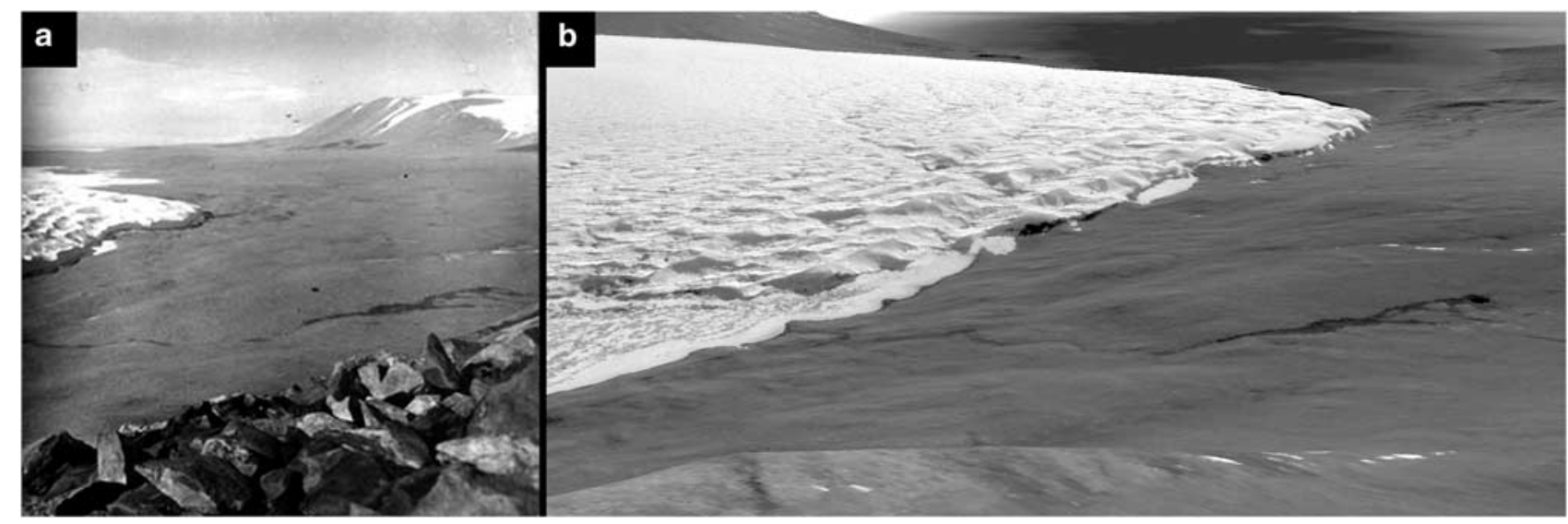

Fig. 5. Comparison on historical and modern images of WT1. a. Photograph of WT1 collected in 1911 by Frank Debenham. WT1 flows through the middle of the frame, down-slope towards Canada Glacier. b. Reconstruction of the image in a. using Ikonos satellite image data (collected 16 January 2010) draped on LiDAR topography data. The location, shape, and extent of wetted soil in WT1 is nearly identical. 
Finally, what is the role of water tracks in the long-term evolution of the Dry Valleys hillslope biological communities? Do water track hydrological conditions avulse across the landscape over time? Within the observational record (c. 100 years) WT1 appears to largely occupy the same broad ice-cement channel in which it is presently observed (Fig. 5). On the timescales of major landscape change in the MDV (typically thousands of years), water tracks may become truncated or abandoned, possibly acting as a solute source for hypersaline wet patches (Levy et al. 2012b). If water tracks are linked to these extremely low water activity soil brine patches, it may indicate that water tracks become increasingly inhospitable to life throughout their development.

\section{Conclusions}

A large water track in the Lake Hoare basin was found to significantly influence the soil ecosystem, affecting the distribution of soil moisture, soil salinity, soil $\mathrm{pH}$, soil carbon, $\mathrm{PO}_{4}{ }^{3-}$, and biology in on track and off track soils. Water track soils also have significantly smaller populations of nematodes than typical MDV soils. Scottnema was the only nematode found in any abundance in the water tracks, and strikingly, circumwater track nematode populations were almost two orders of magnitude smaller than nematode populations reported for soils distant from water tracks. Water track control on top consumer populations is consistent with soil salinities in excess of the habitat maximum reported for halo-tolerant nematodes. Thus, water tracks appear to be a distinct ecosystem feature in the Antarctic soil environment and are a largely unsuitable habitat for invertebrates. Finally, phosphate is depleted in the water track soils, while nitrogen (as $\mathrm{NO}_{2}{ }^{-}$and $\left.\mathrm{NO}_{3}{ }^{-}\right)$is abundant in the water track, suggesting the possibility of phosphate removal by microbial metabolism or hydrological processes in water tracks coupled with nitrogen enrichment from snowmelt. In summary, water tracks are found to significantly affect hillslope ecosystems by modifying soil water content, salinity, nutrient availability, and biological activity for off track and on track soils. Water tracks operate at kilometre length scales across the landscape, providing long-range spatial structure to Antarctic terrestrial ecosystems.

\section{Acknowledgements}

This work is supported by the Antarctic Organisms and Ecosystems Program in the Antarctic Sciences Division of the National Science Foundation (grant \#ANT-0851965 and \#ANT-1142184 to JSL and the MCM-LTER, award ANT-1115245). Quickbird image data was provided courtesy of Dr Paul Morin and the Polar Geospatial Information Centre. LiDAR topography was kindly made possible through a joint effort from the NSF, NASA, and the USGS, with basic post processing from the Byrd Polar Research Center. Also, thanks to Dr Adrian Howkins for access to archival photographs of WT1. This project has benefited greatly from discussion with MCM-LTER team members (www.mcmlter.org), from two anonymous reviewers, and from field and laboratory assistance from Kevin Geyer, Deb Leslie, Thomas Nylen, and Steve Wilson. Finally, we would like to thank Dr J. Reed Glassmann of Willamette Geological Service for XRD analysis services.

\section{References}

Barrett, J.E., Gooseff, M.N. \& Takasc-Vesbach, C. 2009. Spatial variation in soil active-layer geochemistry across hydrologic margins in polar desert ecosystems. Hydrology and Earth Systems Science, 13, 2349-2358

Barrett, J.E., Virginia, R.A., Wall, D.H., Parsons, A.N., Powers, L.E. \& Burkins, M.B. 2004. Variation in biogeochemistry and soil biodiversity across spatial scales in a polar desert ecosystem. Ecology, 85, 3105-3118.

Barrett, J.E., Virginia, R.A., Lyons, W.B., McKnight, D.M., Priscu, J.C., Doran, P.T., Fountain, A.G., Wall, D.H. \& Moorhead, D.L. 2007. Biogeochemical stoichiometry of Antarctic dry valley ecosystems. Journal of Geophysical Research, 10.1029/2005JG000141.

Bate, D.B., Barrett, J.E., Poage, M.A. \& Virginia, R.A. 2008. Soil phosphorus cycling in an Antarctic polar desert. Geoderma, 144(1-2), 21-31.

Bockheim, J.G., Campbell, I.B. \& McLeod, M. 2007. Permafrost distribution and active-layer depths in the McMurdo Dry Valleys, Antarctica. Permafrost and Periglacial Processes, 18, 217-227.

Bockheim, J.G., Prentice, M.L. \& McLeod, M. 2008. Distribution of glacial deposits, soils, and permafrost in Taylor Valley, Antarctica. Arctic, Antarctic, and Alpine Research, 40, 279-286.

Bowden, W.B., Gooseff, M.N., Balser, A., Green, A., Peterson, B.J. \& BRADFORD, J. 2008. Sediment and nutrient delivery from thermokarst features in the foothills of the North Slope, Alaska: potential impacts on headwater stream ecosystems. Journal of Geophysical Research, 10.1029/2007JG000470.

CAmpBell, I.B. 2003. Soil characteristics at a long-term ecological research site in Taylor Valley, Antarctica. Australian Journal of Soil Research, 41, 351-364.

Campbell, I.B., Claridge, G.G.C., Balks, M.R. \& Campbell, D.I. 1997. Moisture content in soils of the McMurdo Sound and Dry Valley region of Antarctica. In Lyons, W.B., Howard-Williams, C. \& Hawes, I., eds. Ecosystem processes in Antarctic ice free landscapes. Rotterdam: Balkema, 61-76.

Cheng, W. \& Virginia, R.A. 1993. Measurement of microbial biomass in arctic tundra soils using fumigation-extraction and substrate-induced respiration procedures. Soil Biology and Biochemistry, 25, 135-141.

Clow, G.D. McKay, C.P., Simmons Jr, G.M. \& Wharton JR, R.A. 1988. Climatological observations and predicted sublimation rates at Lake Hoare, Antarctica. Journal of Climatology, 1, 715-728.

Courtright, E.M., Wall, D.H. \& Virginia, R.A. 2001. Determining habitat suitability for soil invertebrates in an extreme environment: the McMurdo Dry Valleys, Antarctica. Antarctic Science, 13, 9-17.

Decker, E.R. \& Bucher, G.J. 1980. Geothermal studies in Antarctica. Antarctic Journal of the United States, 12(4), 102-104.

Doran, P.T., McKay, C.P., Clow, G.D., Dana, G.L., Fountain, A.G., Nylen, T. \& Lyons, W.B. 2002. Valley floor climate observations from the McMurdo Dry Valleys, Antarctica, 1986-2000. Journal of Geophysical Research, 10.1029/2001JD002045.

Freckman, D.W. \& Virginia, R.A. 1997. Low-diversity Antarctic soil nematode communities: distribution and response to disturbance. Ecology, 78, 363-369. 
Freckman, D.W., Kaplan, D.T. \& van Gundy, S.D. 1977. A comparison of techniques for extraction and study of anhydrobiotic nematodes from dry soils. Journal of Nematology, 9, 176-181.

Hagedorn, B., Sletten, R.S. \& Hallet, B. 2007. Sublimation and ice condensation in hyperarid soils: modeling results using field data from Victoria Valley, Antarctica. Journal of Geophysical Research, 10.1029/ 2006JF000580.

Harris, K.J., CArey, A.E., Lyons, W.B., Welch, K.A. \& Fountain, A.G. 2007. Solute and isotope geochemistry of subsurface ice melt seeps in Taylor Valley, Antarctica. Geological Society of America Bulletin, 119, 548-555.

Hastings, S.J., Luchessa, S.A., Oechel, W.C. \& Tenhunen, J.D. 1989. Standing biomass and production in water drainages of the foothills of the Philip Smith Mountains, Alaska. Holarctic Ecology, 12, 304-311.

Kennedy, A.D. 1993. Water as a limiting factor in the Antarctic terrestrial environment: a biological synthesis. Arctic and Alpine Research, 25, 308-315.

Levy, J. 2012. Hydrological characteristics of recurrent slope lineae on Mars: evidence for liquid flow through regolith and comparisons with Antarctic terrestrial analogs. Icarus, 219, 1-4.

Levy, J.S., Fountain, A.G., Welch, K.A. \& Lyons, W.B. 2012 b. Hypersaline "wet patches" in Taylor Valley, Antarctica. Geophysical Research Letters, 10.1029/2012GL050898.

Levy, J.S., Fountain, A.G., Gooseff, M.N., Welch, K.A. \& Lyons, W.B. 2011. Water tracks and permafrost in Taylor Valley, Antarctica: extensive and shallow groundwater connectivity in a cold desert ecosystem. Geological Society of America Bulletin, 10.1130/B30436.30431.

Levy, J., Fountain, A., Gooseff, M., Barrett, J., Wall, D., Nielsen, U., Adams, B. \&, Lyons, W.B. 2012a. Active layer processes in the McMurdo Dry Valleys, Antarctica: decadal trends and experimental responses to changes in soil moisture. In Hinkel, K.M., ed. Proceedings of the Tenth International Conference on Permafrost, June 2012, Salekhard, Russia, 221-226.

Lyons, W.B., Fountain, A.G., Doran, P.T., Priscu, J.C., Neumann, K. \& Welch, K.A. 2000. Importance of landscape position and legacy: the evolution of the lakes in Taylor Valley, Antarctica. Freshwater Biology, 43, 355-367.

Lyons, W.B., Welch, K.A., Carey, A.E., Wall, D.H., Virginia, R.A., Fountain, A.G., Doran, P.T., Csatho, B.M. \& Tremper, C.M. 2005. Groundwater seeps in Taylor Valley, Antarctica: an example of a subsurface melt event. Annals of Glaciology, 40, 200-207.

Marchant, D.R. \& Head, J.W. 2007. Antarctic dry valleys: microclimate zonation, variable geomorphic processes, and implications for assessing climate change on Mars. Icarus, 192, 187-222.
McGinnis, L.D. \& Jensen, T.E. 1971. Permafrost-hydrogeologic regimen in two ice-free valleys, Antarctica, from electrical depth sounding. Quaternary Research, 1, 31-38.

McNamara, J.P., Kane, D.L. \& Hinzman, L.D. 1999. An analysis of an arctic channel network using a digital elevation model. Geomorphology, 29, 339-353.

McNamara, J.P., Kane, D.L., Hobbie, J.E. \& Kling, G.W. 2008. Hydrologic and biogeochemical controls on the spatial and temporal patterns of nitrogen and phosphorus in the Kuparuk River, Arctic Alaska. Hydrological Processes, 22, 3294-3309.

Michalski, G., Bockheim, J.G., Kendall, C. \& Thiemens, M. 2005. Isotopic composition of Antarctic dry valley nitrate: implications for $\mathrm{NO}(\mathrm{y})$ sources and cycling in Antarctica. Geophysical Research Letters, 10.1029/2004GL022121.

Nielsen, U.N., Wall, D.H., Adams, B.J., Virginia, R.A., Ball, B.A., GoosefF, M.N. \& McKnight, D.M. 2012. The ecology of pulse events: insights from an extreme climatic event in a polar desert ecosystem. Ecosphere, 10.1890/ES1811-00325.00321.

Nkem, J.N., Virginia, R.A., Barrett, J.E., Wall, D.H. \& Li, G. 2006. Salt tolerance and survival thresholds for two species of Antarctic nematodes. Polar Biology, 29, 643-651.

Poage, M.A., Barrett, J.E., Virginia, R.A. \& Wall, D.H. 2008. The influence of soil geochemistry on nematode distribution, McMurdo Dry Valleys, Antarctica. Arctic, Antarctic, and Alpine Research, 40, 119-128.

Powers, L.E., Ho, M., Freckman, D.W. \& Virginia, R.A. 1998. Distribution, community structure, and microhabitats of soil invertebrates along an elevation gradient in Taylor Valley, Antarctica. Arctic, Antarctic, and Alpine Research, 30, 133-141.

Smith, T.E., Wall, D.H., Hogg, I.D., Adams, B.J., Nielsen, U.N. \& VIRGINIA, R.A. 2012. Thawing permafrost alters nematode populations and soil habitat characteristics in an Antarctic polar desert ecosystem. Pedobiologia, 55, 75-81.

Stieglitz, M., Shaman, J., McNamara, J., Engel, V., Shanley, J. \& KLING, G.W. 2003. An approach to understanding hydrologic connectivity on the hillslope and the implications for nutrient transport. Global Biogeochemical Cycles, 10.1029/2003GB002041.

Virginia, R.A. \& WaLl, D.H. 1999. How soils structure communities in the Antarctic dry valleys. BioScience, 49, 973-983.

Welch, K.A., Lyons, W.B., Whisner, C., Gardner, C.B., GoosefF, M.N., McKnight, D.M. \& Priscu, J.C. 2010. Spatial variations in the geochemistry of glacial meltwater streams in Taylor Valley, Antarctica. Antarctic Science, 22, 662-672. 